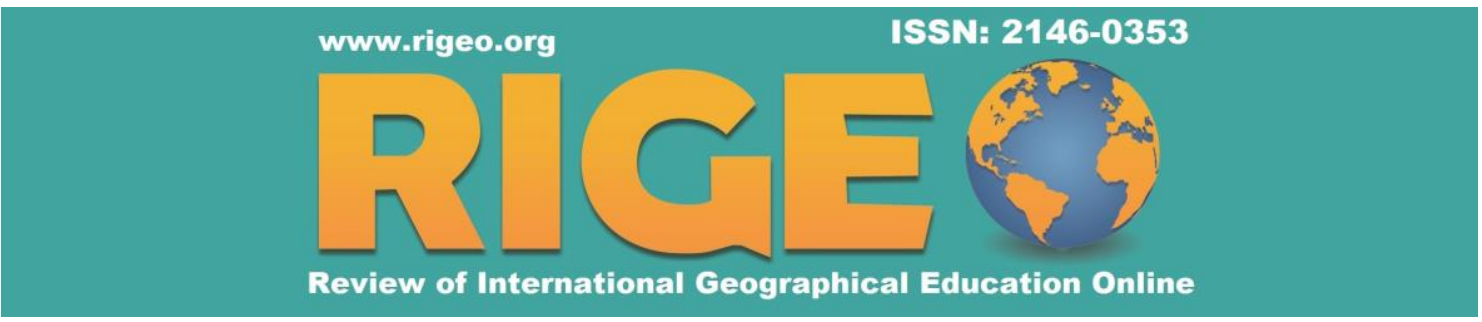

To cite this article: Inel, Y. (2018). The Effect of 4 mat Method on The Academic Achievement of Students in Social Studies Education. Review of International Geographical Education Online (RIGEO), 8(3), 440-458. Retrieved from http://www.rigeo.org/vol8no3/Number3winter/RIGEO-V8-N3-2.pdf

Submitted: September 3, 2018

Revised: December 5, 2018

Accepted: December 9, 2018

\title{
The Effect of Using the 4MAT Teaching Method in 6th-Grade Social Studies Education on the Academic Achievement of Students*
}

\author{
Yusuf İNEL ${ }^{1}$ \\ Uşak University, Uşak, TURKEY
}

\begin{abstract}
The goal of this research is to reveal out the effect of the activities prepared based on the 4MAT teaching method on the academic achievement of the students, with respect to the unit, "The Journey of Democracy", included in social studies curriculum for 6th-graders. In accordance with this goal, the research was conducted using the Solomon four-group experimental model. The study group of the research consisted of 80 sixth graders studying, in the 2017-2018 academic year, at a public secondary school in Merkezefendi district of Denizli province located in the west of Turkey. The research was conducted in a total of four different classes each of which consisted of 20 students. Classes 6/A and 6/C made up the experiment group whereas classes 6/B and 6/D made up the control group. An achievement test developed by the researcher, consisting of 25 questions, with a KR20 value of .80, was used as the mean of data collection. Four options were offered for each question included in the achievement test and the students were asked to mark the option they deemed to be true. In the analysis of the data, frequency, arithmetic mean, percent, standard deviation; and t-test and covariance (ANCOVA) tests among the difference tests, were used. At the end of the research, it was concluded that the 4MAT teaching method was more effective than the existing teaching method in improving the academic achievement of the students with respect to the unit 'The Journey of Democracy".
\end{abstract}

\section{Keywords}

Social Studies; Achievement; 4MAT Teaching Model; Secondary School Students; Solomon Experimental Design

With the effect of the constructivist learning approaches, it has become the basic principle of the contemporary education that each student builds knowledge in a

${ }^{1}$ Assist. Prof.; Faculty of Education, Uşak University, Uşak, Turkey, E-mail: yusuf.inel [at] usak.edu.tr

(C) Review of International Geographical Education Online

RIGEO 2018

ISSN: 2146-0353

www.rigeo.org 
different way in his/her own mind. New approaches to teaching differentiate the quality of the school concept and learning methods. Traditional learning methods and techniques have been abandoned and activities in which students are active in every step of the learning process have gained importance. As a result of this situation, learning contexts where the teacher is dominant and the students are passive listeners have disappeared in time. Teaching practices involving group problem-solving and cooperative learning methods, where the students build knowledge in their own mind, form the basis of the modern constructivist education. The teaching process is affected by the personal differences among students (Woolfolk, 1993). Individual differences are taken into consideration in the learning process, based on the notion that students have different cognitive and affective qualities due to factors such as the past experiences of students, environmental conditions and genetic qualities (Aktaş and Bilgin, 2012). Due to the fact that cognitive, affective and social factors influence the learning process, it is necessary to consider these factors in order for the students to realize themselves and to generate individual meanings. For this reason, it is important for the students to perform activities that would suit their personal areas and interests, to enable their development in all aspects. A teacher who is aware of this shall take the advantage of the fact that students have different past experiences and intellectual capacities and they shall prepare learning activities accordingly (Tomlinson, 2007).

Kolb (trn. from 1984, Bilgin and Bahar, 2008) defines learning style as the method preferred by the individual in the perception and processing stages. Dunn and Dunn (1993) define learning style as the way followed by each student, which starts with the student's beginning of studying upon new and difficult academic information or skill and continues until the adopted information and skills are transferred to the mind. Determination of students' learning styles may help the teachers get an idea about the method to be developed for the teaching contexts intended for the students (Akkoyunlu, 1995). A teacher who knows about the learning styles of students won't have trouble in organizing the learning context according to the features of the students (Babadoğan, 2000). Consequently, they will organize their own teaching style according to the learning styles of the students. Scales (2000) emphasizes that such a learning environment will have a positive effect on student achievement. Learning contexts that are designed according to different learning styles based on the notion that each student learns in a unique style, will be able to meet the needs and interests of all students. As a result, students will be more motivated and participate in class (McCarthy, 2000). Literature studies support that classroom environments that are designed according to the learning styles have positive effect on the academic achievement of students (Aktaş, 2011; Altınok, 2003; Ardıç, 2013; Azizoğlu and Çetin, 2009; Bilgin and Bahar, 2008; Demirkaya, 2003; Dunn and Dunn, 1993; Dunn, Grannitti, Murray, Rossi and Quinn, 1990; Ergin, 2011; Karataş, 2004; Koçak, 2007; Kolay, 2008; Kolb, 1981; Kvan and Yunyan, 2005; McCarthy, 1987; Peker, 2003; Tsai, 2004; Usta, Bodur, Yağız and Sünbül, 2011; Williams and Turner, 2004).

Review of the relevant literature studies revealed out that different classifications were made on learning styles (Dunn and Dunn, 1993; Felder, 1988; Gregorc, 1984; Kolb, 1981). This research covers the 4MAT (4 Mode Applications Techniques) 
learning style. The 4MAT teaching style developed by McCarthy in consideration of the learning styles of the students and the features of the right and left hemisphere is an eight-stage learning cycle that is based on the constructivist system (Ergin and Sar1, 2016; McCarthy, Germain, and Lippitt, 2006; Scott, 1994). The 4MAT learning method is visualized in Figure 1.

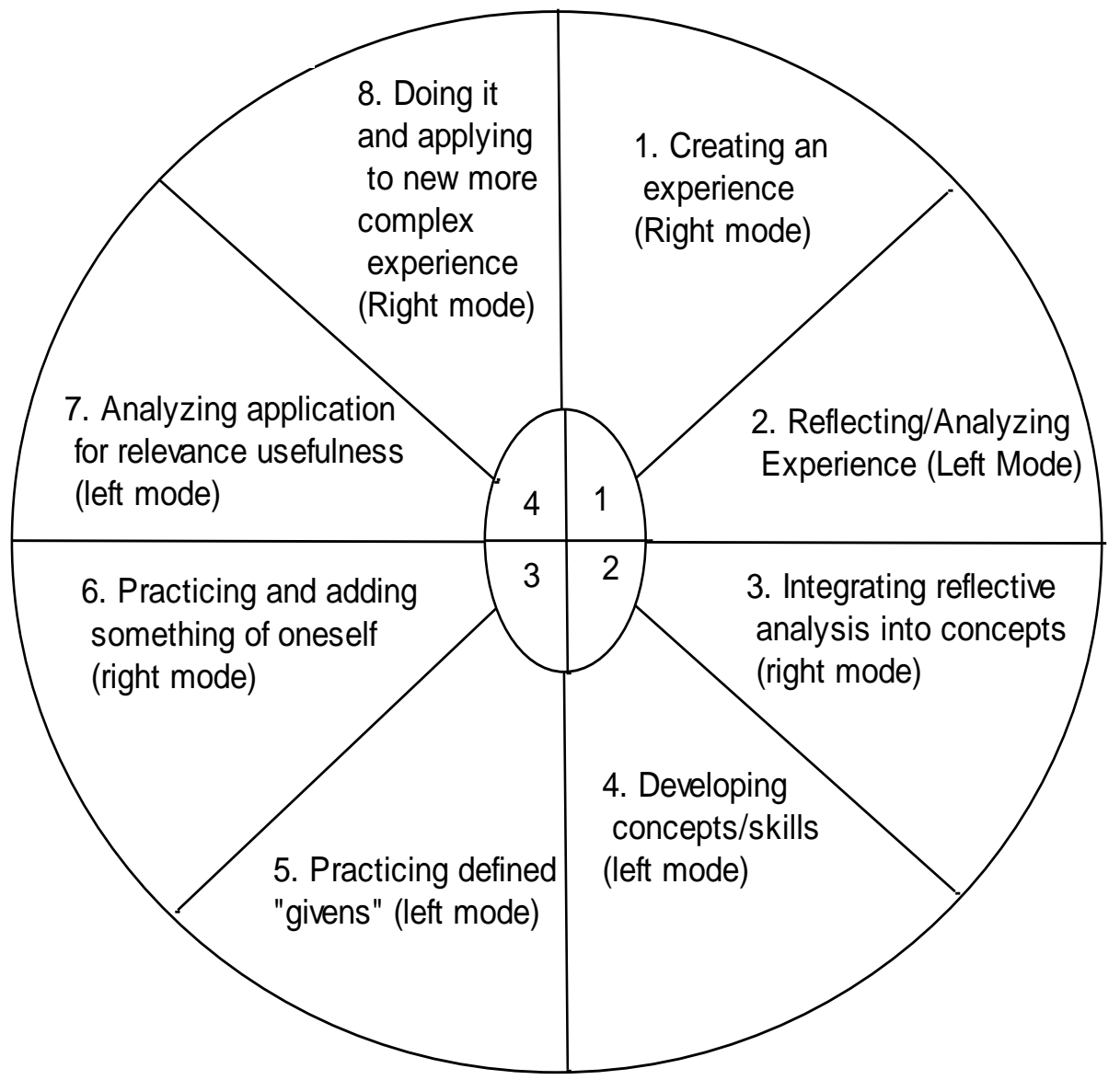

Figure 1. The 4MAT Teaching Method (McCarthy, 1985)

As can be seen in Figure 1, learning styles are divided into four as type one imaginative learners, type two analytical learners, type three common sense learners and type four dynamic learners (McCarthy, 1987, 2000). Each quarter is divided into two parts based on the right-left hemisphere qualities of the brain. These two parts in the quarters are called as 'phase' or 'step'. The first and second steps are for the imaginative learners, the third and fourth steps are for the analytical learners, the fifth and sixth steps are for the prudent learners and the seventh and eighth steps are for the dynamic learners. When organizing the learning contexts, teachers must consider these phases and apply the steps one by one (Ergin and Sar1, 2015). The mobility around the 4MAT learning cycle creates the learning itself. This mobility starts from the dimension of experience and extends to reflection, conceptualization, problem-solving and individual's identification of himself/herself with new information. In this model, information is perceived from the tangible to the intangible and is processed from 
reflection to application in a clockwise direction (Demirkaya, Mutlu, and Uşak, 2003; McCarthy, 2000). Brief descriptions are provided below for each quarter forming the 4MAT learning method.

Imaginative learners (type one) perceive information through tangible experience and internalize it through reflective observation. They identify their experiences with themselves. They listen to opinions and learn by sharing. They are imaginative thinkers who care about their personal experiences. They are successful in gaining experience from different perspectives. Understanding the core meaning of the things they have learned and reflected on these, are important for them. They would like to find an answer to the question "Why?" (Demirkaya et al., 2003; McCarthy, 2000; Mutlu and Okur, 2012).

Analytical learners (type two) perceive information in abstract form and process by reflecting. They integrate their observations with previous knowledge and experience. They care about and respect the opinions of experts. They learn by thinking through experiences and ideas, assessing the accuracy of the information they have faced. They believe that information should be resolved down to the last detail, through systematic and critical thinking. As they prefer to work in an independent and autonomous manner, techniques like mental exercises, plain speech, and question-answer are ideal for analytical learners. For this reason, the classical classroom environment is very suitable for the students in this quarter. They would like to find an answer to the question "What?" (Demirkaya et al., 2003, Ergin and Sar1, 2015; McCarthy, 2000).

Prudent learners (type three) perceive information through abstract conceptualization and internalize it through active experience. The information they have obtained should be useful and usable in real life. They would like to put their theoretical knowledge into practice. They tend to learn by exploring, experimenting and by carrying out manual work. Therefore, they don't like when the solution to a problem is provided in advance. They would rather work on it themselves. The question to be asked for these learners is, "How?". They give importance to the way the information they have learned works and they would like to see its reflections in practice (Demirkaya et al., 2003; Ergin and Sar1, 2015; McCarthy, 2000).

Dynamic learners (type four) learn with the trial-and-error method. They love to explore and they are open to innovations. New things excite dynamic learners. They like to take risks and try new things. They have a strong intuition and they use this capability in problem-solving. They are willing to be active and to take part in activities in the learning process. They have good communication and persuasion skills. Consequently, they are very comfortable with the people around them. It is boring for them to be at school because of their impatient and exciting nature. They think that the school does not respond to their interests and needs. Dynamic students are willing to find an answer to the question "What if?" (Demirkaya et al., 2003; Ergin and Sar1, 2015; McCarthy, 2000). 
A brief information on the steps to be followed for successful implementation of the 4MAT is given below:

Step 1 (Establishing Relationship): Relationships are established between the content and daily life experiences of the students. Thus, the students get an idea whether the subject will be of use to them in their real life. When students see that the information will be of use in everyday life, they will be more motivated to the class (McCarthy and McCarthy, 2006).

Step 2 (Widening the Scope): The objective in this step is to carry our classroom resolutions of the activities performed in the previous step and to enable the students to develop empathy (Ergin and Sar1, 2015). When the students discuss the experiences by observing them, they will better understand the relationships and differences between events. In this step, teachers refrain from influencing students by not declaring their own ideas. Events are resolved by students. Teachers encourage the students by leading them to resolve the experience given in the first step (Ergin and Sar1, 2015).

Step 3 (Visualizing): In this step, teachers should carefully select the information relating to the real life of the students, before giving them content information and should help them learn the content through visualization, visual comparison, and analogy. In this way, it will be easier for the students to learn the things taught by teachers, as they will feel that they already know the topic (Demirkaya et al., 2003).

Step 4 (Informing): The students are familiar with the content owing to the practices of the first three steps (McCarthy, 2000). In this step, teachers lecture the students. The teacher is the lecturer in the class and the students are the listeners. While teachers lecture on a topic covering the finest details, students take notes and ask the teacher to repeat the things they have not understood. The questions in the minds of the students are tried to be solved in this way (Demirkaya et al., 2003).

Step 5 (Applying): In this step, the students apply the information they have acquired and turn that into reality. The goal in this step is to enable students to acquire skills in parallel with the information they have acquired and to help them transfer their knowledge to their real life (Demirkaya et al., 2003, Ergin and Sar1, 2015).

Step 6 (Inventing): In this step, students transfer their knowledge to new situations in a concrete manner. They have now acquired a sufficient amount of content. They wonder about the application of their theoretical knowledge and learn through trial-anderror. In this step where manual skills are heavily used, all of the students are engaged in different subjects and will reach actual satisfaction at the end of the process (Demirkaya et al., 2003; McCarthy, 2000; McCarthy and McCarthy, 2006).

Step 7 (Idealising): In this step, the students step back and study their output. They assess their own products like a person observing the situation as an outsider. Besides self-assessment, they assess each other's product as the whole class in order to reach perfection. In this step, the teacher makes various suggestions to help the students (Demirkaya et al., 2003; McCarthy, 2000; McCarthy and McCarthy, 2006). 
Step 8 (Model Building): In this step, students exhibit their products and present them to friends and school. In this step, the students show everybody, including particularly their teachers and classmates, what they have comprehended, to what extent they are related with the content they have learned, their relationship with more holistic views and how much they fit their life. Their communication skills are developed by enabling them to share their outputs and answer the questions (Demirkaya et al., 2003; Ergin and Sar1, 2015; McCarthy, 2000; McCarthy and McCarthy, 2006).

According to McCarthy (2000), all students find a place in one of the four quarters of the cycle. Due to the fact that there is a student in each quarter, teachers need to prepare a learning environment that would be suitable for every learning style. The whole cycle is more valuable than any part of it; because the learning activity in each quarter cycle ensures a better understanding for the students there and the learning activities in other quarters make it possible for the students to get used to the learning styles other than their own learning styles. As a result of this situation, students are influenced by each other and they renew their learning styles (Bülbül and Özsoy, 2016). The 4MAT learning cycle and its application steps show that 4MAT learning style establishes a bond between content and real life, and thus, is important in creating new ideas and turning knowledge into experience. From this point of view, the 4MAT learning method can be used as an effective method to improve the academic achievement of students, as it is able to meet different learning styles and respond to the question why the students should learn the topics (Cengizhan and Özer, 2016). Review of the relevant literature studies show that the 4MAT learning method has positive effects on the academic achievement of the students (Ardıç, 2013; Aydıntan et al., 2012; Cengizhan and Özer, 2016; Ergin and Sarı, 2012, 2015; Demirkaya, 2003; Dikkartın-Övez, 2012; Gökdağ, 2004; Hsieh, 2003; Mutlu, 2004; Peker, 2013; Özgen and Alkan, 2014; Öztürk, 2007; Uyganör and Dikkartın, 2009; Uysal, 2009). There were no studies using the 4MAT teaching method in social studies education. Within this context, the goal of this research is to reveal out the effect of activities prepared based on the 4MAT teaching method on the academic achievement of the students, with respect to the unit, "The Journey of Democracy", included in social studies curriculum for 6th-graders. The following questions (sub-goals) were inquired within the scope of the general goal of the research:

- Is there a significant difference between the pre-test scores of the experimental and control group students who took the pre-test?"

- Is there a significant difference between the post-test scores of the experimental group students who took the pre-tests and who didn't?

- Is there a significant difference between the post-test scores of the control group students who took the pre-test and who didn't?

- Is there a significant difference between the pre-test and post-test scores of the experimental group students who took the pre-test?"

- Is there a significant difference between the pre-test and post-test scores of the control group students who took the pre-test? 
- Is there a significant difference between the experimental and control group students who took the pre-test, with respect to their post-test scores which were corrected according to the academic achievement pre-test scores?

\section{Methodology}

\section{Research Model}

This research, which is conducted to determine the way activities prepared based on the 4MAT teaching method influence the academic achievement of students, has been designed according to the Solomon four-group model. In this research, the 4MAT teaching method is the independent variable and the academic achievement level of the students is the dependent variable. In the Solomon model, research subjects are randomly assigned to two experimental and two control groups and only one experimental and one control group are pre-tested. All four groups take the post-test following the experimental study. The purpose of the four-group Solomon model is to determine the effect of the pre-test (which is applied prior to the experimental study) on the dependent variable. The results of the post-tests applied to two experimental and two control groups are compared. If the two experimental groups have similar results, and likewise, if the results of the two control groups are the same, it is concluded that the pre-test has no influence on the dependent variable. However, if the results of the two groups which took the pre-test are different from the other two groups which did not, then it is concluded that the pre-test has an influence on the dependent variable (Neuman, 2009).

\section{Working Group}

The study group of the research consisted of 80 sixth graders studying, in the 20172018 academic year, at a public middle school in Merkezefendi district of Denizli province located in the west of Turkey. The research was conducted in four different classrooms. Each classroom consisted of 20 students. Classes 6/A and 6/C made up the experiment group whereas classes $6 / \mathrm{B}$ and $6 / \mathrm{D}$ made up the control group. Experimental and control groups were randomly assigned. Class 6/A consisted of 13 boys and 7 girls; Class 6/B consisted of 11 girls and 9 boys; Class 6/C-consisted of 12 boys and 8 girls and Class 6/D consisted of 13 boys and 7 girls.

\section{Data Collection Tool}

In the research conducted to determine the effect of teaching with 4MAT teaching method on students' academic achievement, with respect to the unit 'The Journey of Democracy', an achievement test consisting of 25 questions developed by the researcher, was used as the data collection tool. Four options were offered for each question included in the achievement test and the students were asked to mark the option they deemed to be true.

\section{Validity and Reliability of the Data Collection Tool}

In order to develop the achievement test, a total of 51 multiple-choice questions were prepared for the five acquisition involved in unit 'The Journey of Democracy'. To ensure the content validity of the questions 3 expert academicians were consulted. In addition, 
a pilot study was conducted with 200 seventh-graders studying at a secondary school located in Merkezefendi district of Denizli province, in order to measure validity and reliability.

The data obtained after the pilot study were exposed to item analysis as the lower group (27\%) and the higher group (27\%) in terms of achievement rank. The difficulty and distinctiveness indices of the items were measured in this analysis. 26 questions with a level of distinctiveness lower than 30, were excluded from the test and 7 items were modified. The final achievement test consisted of 25 questions with item difficulty indices changing from .46 to 81 . In addition, the KR20 reliability coefficient was measured using the item covariance. KR20 reliability covariance was measured as .803 .

\section{Data Analysis}

The data obtained were analysed using the SPSS 22.0 program. Correct answers in the achievement test were coded as 1 and wrong answers were coded as 0 . Frequency $(\mathrm{f})$, arithmetic mean $(\overline{\mathrm{X}})$, percentage $(\%)$, standard deviation (s) and t-test were used in the comparative analysis of the achievement scores of the groups. In addition, covariance (ANCOVA) analysis was conducted to determine whether the changes in the academic achievement scores of the experimental and control groups displayed a significant difference before and after the experiment.

\section{The Experimental Process}

Before the experimental process, Class 6/A, from the experimental group and Class $6 / \mathrm{B}$, from the control group were pre-tested. For the five gains involved in the unit "The Journey of Democracy", five lesson plans intended for the eight steps of the 4MAT teaching method were developed and applied to the experimental groups. Applications were performed in a total of 16 class hours. Applications were performed between April 18, 2017 - May 18, 2017. In the control groups, lessons were taught as prescribed by the curriculum. The experimental and control groups took post-test after the applications. Below is a 4MAT teaching method-based sample lesson plan, which is prepared for the first gain of the unit "The Journey of Democracy".

Step 1: Establishing Relationship

Goal: To generate an experience in which students can relate to the goal of the lesson.

Activity: Students are divided into 4 groups and each group is assigned a topic related to regimes. The groups make research about the topics they have chosen. They prepare a relevant drama activity about Monarchy, Theocracy, Oligarchy, and Democracy and demonstrate it in the class. Consequently; they learn the topic by experiencing it.

Materials: Clipboard, Posters, relevant clothes.

Evaluation: The quality of student participation and observation.

Step 2: Widening the Scope

Goal: To make a comparative analysis of different management models. 
Activity: Individual differences in listening activities are discussed and analysed taking individual and group differences into consideration.

Evaluation: Quality of student participation in discussion

Step 3: Visualizing

Goal: To visualize the regimes and historical development of democracy.

Activity: Students will be able to tell how they feel about democracy and regimes and by which means they explain those. They can demonstrate by way of fine arts, drama, modelling, and role-playing.

Evaluation: The quality of student productivity.

Step 4: Informing

Goal: To teach the regimes and democracy.

Activity: Information, the accuracy of which is confirmed in relation with the concept, is accessed and learned. Students choose the regimes they will explore. The teacher prepares the basic information required to be explored (regimes, the historical development of democracy, regimes followed by Turkish people, etc.) and gives these to the students. These topics are also explained by the teacher.

Students get satisfied with the topic by receiving accurate information. Then, views are exchanged with the students. The teacher creates this environment to help the students make an individual review. The interview technique is applied in this step.

Evaluation: The teachers check the students' level of understanding.

Step 5: Applying

Goal: To study the predefined concepts.

Activity 1: Basic topics about regimes are determined and research is initiated. First, necessary information about the relevant topic is obtained from science books. For example; the habitat of big cats/various colours on the backs of animals. The goal here is to help the students to be able to define the basic concepts related to the topic.

Activity 2: The activity starts by discussing the issue that, regimes are one of the most important indicators of a society and its level of development. After the discussion, the students try to match the regime they have chosen with concepts defined in the workbook and to establish a relationship. Then the students find pictures related to the regimes they have chosen and prepare a brochure.

Activity 3: The students think over and discuss, individually and in groups, the regimes of societies and the pictures shown.

Evaluation: Completion of the task, the quality of the completed draft.

Step 6: Inventing

Goal: To improve the students' levels of understanding and analysis of the topic 
Activity: The students are asked to write an essay about what they have learned in the unit. They should add their own opinions in this essay. Oral interview and persuasive paragraphs are read to the students. They are asked to include photos in the brochures. The teacher informs the students about how to access further information about the topic. A geographical and historical atlas is used to compare the past and present regimes of countries. A symbol is set to show the differences between them. Students should find a title to the essay which involves their opinions about the topic, as well. The title should be clear. The map could be mounted on a clipboard or on cardboard for visibility. The teacher supplies the necessary maps related to the topic. Evaluation: Participation, quality of the work done, completion of work, accuracy, and willingness.

Step 7: Idealising

Goal: To show how to use in future learning

Activity: Idealising persuasive paragraphs and oral interviews

Evaluation: The quality of the work, willingness, expression of ideas

Step 8: Modelling

Goal: To share the outputs and get pleasure from them.

Activity: Finally, students make their demonstrations. Outputs of the students are exhibited in the hall and on the notice boards available in classrooms. Documentaries about the regimes in history and the development of democracy and women's rights in Turkish society are watched in the end.

Evaluation: Evaluation will be made before starting to work on the unit, through a test consisting of 25 questions each of which has 4 choices.

General Evaluation: Students will be able to analyse the regimes, democracy, and human rights. They will be able to analyse how people were adapted to regimes in order to survive. Furthermore, they will understand that women's rights are among the basic principles of democracy. They will analyse and internalize the other basic principles of democracy.

\section{Findings}

\section{Findings Related to the First Sub-Problem}

The first sub-problem of the research is, "Is there a significant difference between the pre-test scores of the experimental and control groups?" T-test for independent groups was conducted to solve the problem. The results achieved are given in Table 1. 
Inel, Y. (2018) / The effect of 4 mat method on the academic achievement of students in social....

Table 1

T-Test Results for the Comparison of the pre-test Scores of the Experimental and Control Group Students Who Took the pre-test

\begin{tabular}{lcccccc}
\hline Group & $\mathbf{N}$ & $\bar{X}$ & $\mathbf{S}$ & Sd & t & $\mathbf{p}$ \\
\hline Experimental & 20 & 6.05 & 3.05 & 38 & .054 & .957 \\
Control & 20 & 6.00 & 2.75 & & & \\
\hline
\end{tabular}

There was no significant difference between the pre-test scores of the experimental and control groups which took pre-tests $\left(\mathrm{t}_{(38)}=.054, \mathrm{p}>.05\right)$. The mean of the control group $(\bar{X}=6.00)$ and the mean of the experimental group $(\bar{X}=6.05)$. It can be concluded from this finding that, the academic achievement levels of the two groups are similar.

\section{Findings Related to the Second Sub-Problem}

The second sub-problem of the research is, "Is there a significant difference between the post-test scores of the students of the experimental group students who took a pretest and who didn't? T-test for independent groups was conducted to solve the problem. The results achieved are given in Table 2.

Table 2

T-Test Results for the Comparison of the post-test Scores of the Experimental Group Which Took the pre-test and Which Didn't

\begin{tabular}{lcccccc}
\hline $\begin{array}{l}\text { The Experimental } \\
\text { Group }\end{array}$ & N & $\bar{X}$ & S & Sd & t & p \\
\hline pre-tested & 20 & 19.00 & 2.32 & 38 & .497 & .622 \\
Not-pre-tested & 20 & 18.65 & 2.13 & & & \\
\hline
\end{tabular}

According to the results of the t-test for independent groups conducted to find out whether there was a significant difference between the post-test scores of the experimental group students who took pre-test and who didn't, there is no significant difference between the post-test scores of the experimental groups $\left(\mathrm{t}_{(38)}=.497, \mathrm{p}>.05\right)$. It can be concluded from this finding that, the academic achievement levels of the groups after the experiment are similar. Moreover, it shows that pre-tests have no didactic effect on the experimental group. The mean post-test achievement score of the experimental group which took the pre-test is, $(\bar{X}=19.00)$ and the mean post-test achievement score of the experimental group which didn't take the pre-test is, ( $\bar{X}=18.65)$.

\section{Findings Related to the Third Sub-Problem}

The third sub-problem of the research is, "Is there a significant difference between the post-test scores of the control groups which took the pre-test and which didn't?" Ttest for independent groups was conducted to solve the problem. The results achieved are given in Table 3 . 
Table 3

T-Test Results for the Comparison of the post-test Scores of the Control Group Which Took the pre-test and Which Didn't

\begin{tabular}{lcccccc}
\hline Control Group & $\mathbf{N}$ & $\bar{X}$ & $\mathbf{S}$ & Sd & t & p \\
\hline pre-tested & 20 & 13.75 & 3.19 & 38 & 7.157 & .000 \\
Not-pre-tested & 20 & 6.75 & 2.99 & & & \\
\hline
\end{tabular}

According to the results of the t-test for independent groups conducted to find out whether there was a significant difference between the post-test scores of the control group students who took pre-test and who didn't, there is a significant difference between the post-test scores of the control groups in favour of the pre-tested control group $\left(\mathrm{t}_{(38)}=7.157, \mathrm{p}<.05\right)$. It can be concluded from this finding that, the pre-tests have a didactic effect on the control group. The mean post-test achievement score of the control group which took the pre-test is, $(\bar{X}=13.75)$ and the mean post-test achievement score of the control group which didn't take the post-test is, $(\bar{X}=6.75)$.

\section{Findings Related to the Fourth Sub-Problem}

The fourth sub-problem of the research is, "Is there a significant difference between the pre-test and post-test scores of the control group which took the pre-test?" T-test for dependent groups was conducted to solve the problem. The results achieved are given in Table 4.

Table 4

T-Test Results for the Comparison of the pre-test and post-test Scores of the Experimental Group Which Took the pre-test

\begin{tabular}{lcccccc}
\hline $\begin{array}{l}\text { Experimental } \\
\text { Group }\end{array}$ & N & $\bar{X}$ & S & Sd & t & p \\
\hline pre-test & 20 & 6.05 & 3.05 & 19 & -22.78 & .000 \\
post-test & 20 & 19.00 & 2.31 & 19 & & \\
\hline
\end{tabular}

According to the results of the t-test for dependent groups conducted to compare the pre-test and post-test scores of the experimental group which took the pre-test, there is a significant difference in favour of the post-test scores $\left(t_{(19)}=-22.78, p<.05\right)$. It can be concluded from this finding that, the 4MAT teaching method improves the academic achievement of students. The mean pre-test score of the experimental group is, $(\bar{X}=6.05)$ and the mean post-test score is, $(\bar{X}=19.00)$.

\section{Findings Related to the Fifth Sub-Problem}

The fifth sub-problem of the research is, "Is there a significant difference between the pre-test and post-test scores of the control group which took the pre-test?" T-test for dependent groups was conducted to solve the problem. The results achieved are given in Table 5 . 
İnel, Y. (2018) / The effect of 4mat method on the academic achievement of students in social....

Table 5

T-Test Results for the Comparison of the pre-test and post-test Scores of the Control Group Which Took the pre-test

\begin{tabular}{lcccccc}
\hline Control Group & $\mathbf{N}$ & $\bar{X}$ & $\mathbf{S}$ & $\mathbf{S d}$ & $\mathbf{t}$ & $\mathbf{p}$ \\
\hline pre-test & 20 & 6.00 & 2.75 & & & \\
post-test & 20 & 13.75 & 3.19 & & -7.815 & .000 \\
\hline
\end{tabular}

According to the results of the t-test for dependent groups conducted to compare the pre-test and post-test scores of the control group which took the pre-test, there is a significant difference in favour of the post-test scores $\left(\mathrm{t}_{(19)}=-7.815, \mathrm{p}<.05\right)$. The mean pre-test score of the control group is $(\bar{X}=6.00)$; and the mean post-test score is, ( $\bar{X}=13.75$ ). It can be concluded from this finding that, the teaching method applied on the control group improves the academic achievement of students.

\section{Findings Related to the Sixth Sub-Problem}

The sixth sub-problem of the research is, "Is there a significant difference between the post-test scores of the pre-tested experimental and control group students, which were corrected according to the academic achievement pre-test scores?" The Covariance analysis (ANCOVA) was used in the comparison of the post-tests, assuming that the significant difference between the post-test scores of the control group which took the pre-test and which didn't, could be arising from the didactic effect of the pre-tests. Before conducting the Covariance analysis, it is necessary to check the homogeneity of variance, whether the regression lines of the dependent variable and control variable are similar or not and whether the control variable and independent variable are independent from each other or not (Can, 2017). Within this context, Levene's test was conducted first for the homogeneity of variances. At the end of the analysis, the significance value was found as .108. This finding shows that the homogeneity of variances is obtained. On the other hand, the significance value of the group*pre-test interaction was found as .068 according to the results of the analysis carried out to check the similarity of the regressions lines of the groups. Since the significance value is above .05 , it can be concluded that the assumption of the homogeneity of the regression lines is confirmed. T-test for independent groups was conducted to check whether the control variable and the independent variable were independent of each other and the pre-test significance value of the groups was found as .957 . This finding shows that the control variable (pre-test) and the independent variable (Group) do not share the variances; which means, they are independent of each other. The covariance (ANCOVA) analysis was conducted once the assumptions were confirmed. The results achieved are given in Table 6. 
Table 6

Corrected post-test Scores of the pre-tested Experimental and Control Group Students

\begin{tabular}{lccc}
\hline Group & $\mathrm{N}$ & Total & Corrected Total \\
\hline Experimental & 20 & 19.00 & 18.98 \\
Control & 20 & 13.75 & 13.74 \\
\hline
\end{tabular}

According to the values given in Table 6, the total post-test score of the experimental group is $\bar{X}=19.00$; and the post-test score of the control group is $\bar{X}=13.75$. The scores corrected according to the pre-tests show that the total post-test score of the experimental group is $\bar{X}=18.98$, and the total post-test score of the control group is $\bar{X}=13.74$. As can be seen, when the pre-test scores of the groups are controlled, there are slight changes in post-test scores.

Table 7 shows the results of the covariance (ANCOVA) analysis conducted to find out whether there is a significant difference between the corrected post-test scores of the experimental and control groups.

Table 7

ANCOVA Results for the Comparison of the post-test Scores of the Experimental and Control Groups Which are Corrected According to the pre-test Scores

\begin{tabular}{llllll}
\hline $\begin{array}{l}\text { Source of the } \\
\text { Variance }\end{array}$ & KT & sd & KO & F & P \\
\hline pre-test & 11.217 & 1 & 11.217 & 1.459 & .235 \\
Group (experimental & 274.623 & 1 & 274.623 & 35.711 & .000 \\
control) & & & & & \\
Error & 284.533 & 37 & 7.690 & & \\
Total & 571.375 & 39 & & & \\
\hline
\end{tabular}

According to the results given in Table 7 , there is a significant difference between the post-test achievement scores of the experimental and control group students $\left[\mathrm{F}_{(1-39)}=\right.$ 7.690; $\mathrm{p}<.05]$. In other words, it can be concluded that the 4MAT teaching model improves the achievement of students.

\section{Conclusions and Discussion}

This study explored the effect of the activities prepared based on the 4MAT teaching method on the academic achievement of the students, with respect to the unit, "The Journey of Democracy", included in social studies curriculum for 6th-graders. The research, which was conducted using the four-group (two experimental, two control groups) Solomon pattern, revealed out no significant difference between the pre-test achievement scores of the experimental and control groups. These results indicate that the groups were randomly assigned prior to the application.

In the research, the post-test scores of the experimental group which took the pre-test was compared with the post-test scores of the experimental group which didn't, in order 
to find out whether the pre-test had a didactic effect on the academic achievement of the students. Research results showed that the pre-test had no didactic effect on the academic achievement of the students in the experimental group. However, the same process was applied to the control group and it was seen that academic achievement levels of the students who took the pre-test were higher than the control group students who did not. These results suggest that pre-testing doesn't have any didactic effect on experimental groups, whereas it has a didactic effect on control groups.

The post-test scores of the pre-tested group (Class 6/A) increased significantly. On the other hand, the post-test scores of the pre-tested control group (Class 6/B) also increased significantly. According to these results, both the 4MAT teaching method and the teaching method prescribed by the existing curriculum (the traditional method) had a positive effect on the academic achievement of the students in the unit "The Journey of Democracy". Given the fact that both methods improved academic achievement, posttest scores of the pre-tested experimental and control groups were compared to determine if the 4MAT teaching method was more effective than the traditional method. The Covariance analysis (ANCOVA) was used in the comparison of the post-tests, assuming that the significant difference between the post-test scores of the control group which took the pre-test and which didn't, could be arising from the didactic effect of the pre-tests. At the end of the analysis, it was concluded that the 4MAT teaching method was more effective than the existing teaching method in improving the academic achievement of the students with respect to the unit 'The Journey of Democracy". These results are consistent with the other researches in literature that are conducted to determine whether the 4MAT teaching method had a positive effect on academic achievement (Ardıç, 2013; Aydıntan et al., 2012; Cengizhan and Özer, 2016; Demirkaya, 2003; Dikkartın-Övez, 2012; Ergin and Sar1, 2012, 2015; Gökdağ, 2004; Mutlu, 2004; Özgen and Alkan, 2014; Öztürk, 2007; Peker, 2003; Tezcan and Güvenç, 2017; Uyangör and Dikkartın, 2009; Uyangör, 2012; Uysal, 2009). It supports this result in researches conducted in different areas abroad (Appell, 1991; Bowers, 1987; Davis, 2007; Hsieh, 2003; Kelly, 1990; Nicoll-Senft, 2012; Nowacki, 2011; Pratoomtong, Haemaprasith, Boonprakob and Choochom, 2012; Ursin, 1995).

It was aimed to support the effect of the 4MAT teaching method on academic achievement with sound proofs using the Solomon pattern. Indeed, our research revealed out in the comparison of the post-test scores of the control groups that the pretested Class 6/B was more successful, which posed an example to the didactic effect of pre-tests. It can be concluded from the research findings that, differentiating the social studies classes according to learning styles would improve academic achievement and boost the students' interest in the class. That longs at the half of one scholar year study, uncovering the effect of the 4math teaching method on student achievement. 


\section{References}

Akkoyunlu, B. (1995). Bilgi teknolojilerinin okullarda kullanımı ve öğretmenlerin rolü. Hacettepe Üniversitesi Eğitim Fakültesi Dergisi, 11, 105-109.

Aktaş, İ. (2011). 4MAT öğretim yöntemine dayalı ögretimin ilköğretim yedinci sınıf ögrencilerinin maddenin yapısl ve özellikleri ünitesindeki başarl, motivasyon ve öğrenme stillerine etkisi. Yayımlanmamış Yüksek Lisans Tezi. Mustafa Kemal Üniversitesi, Sosyal Bilimler Enstitüsü, Hatay.

Aktaş, İ. \& Bilgin, İ. (2012). 4MAT modelinin madde konusunda uygulanmasının ilköğretim 7. sınıf öğrencilerinin öğrenme stillerine etkisinin incelenmesi. Erzincan Üniversitesi Fen Bilimleri Enstitüsü Dergisi, 5(1), 43-63.

Altınok, V. (2003). İlköğretim 6., 7.,8. sınıf ögrrencilerinin ingilizce dersindeki başarılarına göre ögrenme stilleri ve çalışma alışkanlıklarının incelenmesi. Yayimlanmamiş Yüksek Lisans Tezi. Selçuk Üniversitesi Eğitim Bilimleri Enstitüsü, Konya.

Appell, C. J. (1991). The effects of the 4MAT system of instruction on academic achievement and attitude in the elementary music classroom. Unpublished Doctoral Dissertation. University of Oregon, Portland.

Ardıç, E. Ö. (2013). 8. sınıf geometrik cisimler konusunun ögretiminde 4MAT öğretim modelinin etkisi. Yayımlanmamış Yüksek Lisans Tezi. Karadeniz Teknik Üniversitesi Eğitim Bilimleri Enstitüsü, Trabzon.

Aydıntan, S., Şahin, H. \& Uysal, F. (2012). 'Kesirler' konusunun öğretiminde 4mat öğrenme stili modelinin akademik başarı ve kalıc1lığa etkisi. Mehmet Akif Ersoy Üniversitesi Ĕ̈itim Fakültesi Dergisi, 1(23), 408-427.

Azizoğlu, N. \& Çetin, G. (2009). 6 ve 7. sınıf öğrencilerinin öğrenme stilleri, fen dersine yönelik tutumları ve motivasyonları arasındaki ilişki. Kastamonu Eğitimi Dergisi, 17(1), 171-182.

Babadoğan. C. (2000). Öğretim stili odaklı ders tasarımı geliştirme. Milli Eğitim Dergisi, 147, 61-63.

Bilgin, İ. \& Bahar, M. (2008). Sınıf öğretmenlerinin öğretme ve öğrenme stilleri arasındaki ilişkinin incelenmesi. Gazi Ë̆itim Fakültesi Dergisi, 28(1), 19-38.

Bowers, P. S. (1987). The effects of the 4MAT system on achievement and attitudes in science. Unpublished Doctoral Thesis. The University of North Carolina at Chapel Hill.USA.

Bülbül, H. \& Özsoy, V. (2016). 4MAT öğretim modelinin güzel sanatlar lisesi 9. sınıf iki boyutlu sanat atölye dersinde uygulanması. Bartın Üniversitesi Eğitim Fakültesi Dergisi, 5(1), 83-105.

Cengizhan, S. \& Özer, S. (2016). "Oran-Orantı" konusunun öğretiminde 4MAT öğrenme stili modelinin akademik başarı ve öğrenme kalıcılığına etkisi. Eğitimde Kuram ve Uygulama, 12(3), 568-589.

Davis, S. E. (2007). Effects of motivation, preferred learning styles and perception of classroom climate on achievement in ninth and tenth grade math students. Unpublished Doctoral Thesis. University of Florida. 
Inel, Y. (2018) / The effect of 4 mat method on the academic achievement of students in social....

Demirkaya, H. (2003). Coğrafya öğretiminde 4MAT öğretim sisteminin lise coğrafya derslerindeki başari ve tutumlar üzerine etkisi. Yayımlanmamış Doktora Tezi. Gazi Üniversitesi Eğitim Bilimleri Enstitüsü, Ankara.

Demirkaya, H., Mutlu, M. \& Uşak, M. (2003). 4MAT öğretim sistem modelinin çevre eğitimine uygulanması. Pamukkale Üniversitesi Ĕgitim Fakültesi Dergisi, 2(14), 68-82.

Dikkartın-Övez, F. T. (2012). The effect of the 4MAT model on student's algebra achievements and level of reaching attainments. Int. J. Contemp. Math. Sciences, 7(45), 2197-2205.

Dunn, R. S. \& Dunn K. J. (1993). Teaching secondary students through their individual learning styles. Boston, Mass: Allyn Bacon.

Dunn, R., Giannitti, M.C., Murray, J.B., Rossi, I. \& Quinn, G.P. (1990). Grouping students for instruction: effects of learning style on achievement and attitudes. The Journal of Social Psychology, 130(4), 485-494.

Ergin, S. (2011). Fizik ĕgitiminde 4MAT ögretim yönteminin farkli öğrenme stillerine sahip lise ögrencilerinin iş, güç ve enerji konusundaki başarisina etkisi. Yayımlanmamış Doktora Tezi. Gazi Üniversitesi Eğitim Bilimleri Enstitüsü, Ankara.

Ergin, S. \& Sar1, M. (2012). Effects of the 4MAT instruction method on the achievement of high school students with different learning styles on the subjects of work, power and energy in physics. Energy Education Science and Technology Part B: Social and Educational Studies, 4(2), 807-820.

Ergin, S. \& Sarı, M. (2015). 4MAT öğretim yöntemi ve sunuş yoluyla öğretim yöntemine göre öğrencilerin öğrenme stilleri ile başarıları arasındaki ilişkinin araştırılması. Bartın Üniversitesi Ë̆itim Fakültesi Dergisi, 4(1), 178-203.

Ergin, S. \& Sarı, M. (2016). Fizik eğitiminde 4MAT öğretim yönteminin öğrencilerin seçilmiş duyuşsal özelliklerine etkisi. Hacettepe Üniversitesi Eğitim Fakültesi Dergisi, 31(1), 212230.

Felder, R. M. (1988). Learning and teaching styles in engineering education. Engineer Education, 78(7), 674-681.

Gökdağ, M. (2004). Sosyal bilgiler ögrretiminde işbirlikli öğrenme, öğrenme stilleri, akademik başarı ve cinsiyet ilişkileri. Yayımlanmamış Doktora Tezi. Dokuz Eylül Üniversitesi, Eğitim Bilimleri Enstitüsü, İzmir.

Gregorc, A. F. (1984). Style as a symptom: A phenomenological perspective. Theory into Practice, 23(1), 51-56.

Hsieh, H. C. (2003). The effect of whole-brain instruction on student achievement, learning, motivation and teamwork at a vocational high school in Taiwan. Unpublished Doctoral Dissertation. Idaho State University, USA.

Karataş, E. (2004). Bilgisayara giriş dersini veren öğretmenlerin öğrenme stilleri ile dersi alan ögrencilerin öğrenme stillerinin eşleştirilmesinin ögrrenci başarısına etkisi. Yayımlanmamış Yüksek Lisans Tezi. Gazi Üniversitesi, Eğitim Bilimleri Enstitüsü, Ankara.

Kelly, C. (1990). Using 4MAT in law school. Educational Leadership, 48(2), 40-41.

Koçak, T. (2007). İlköğretim 6. 7. ve 8. ögrencilerinin öğrenme stilleri ve akademik başarıları arasındaki ilişkinin incelenmesi (Gaziantep ili merkez ve ilçeleri örneği). 
Yayımlanmamış Yüksek Lisans Tezi. Gaziantep Üniversitesi Sosyal Bilimler Enstitüsü, Gaziantep.

Kolay, B. (2008). Öğretim stillerinin farklı ögrenme stillerine sahip 6. sinı öğrencilerinin fen ve teknoloji dersi başarısı arasındaki iliş̧ki. Yayımlanmamış Yüksek Lisans Tezi. Abant İzzet Baysal Üniversitesi Sosyal Bilimler Enstitüsü, Bolu.

Kolb, D. A. (1981). Learning styles and disciplinary differences. San Fransisco, California: Josey-Bass Inc. Publishers.

Kvan, T. \& Yunyan, J. (2005). Students' learning styles and their correlation with performance in architectural design studio. Design Studies, 26(1), 19-34.

McCarthy, B. (1985). What 4MAT training teaches us about staff development. Educational Leadership, 42(7), (61-68).

McCarthy, B. (1987). The 4MAT system: Teaching to learning styles with right/ left mode techniques. Barrington: Excel Inc.

McCarthy, B. (2000). About teaching 4MAT in the classroom. Illionois: About Learning Inc.

McCarthy, B., \& McCarthy, D. (2006). Teaching around the 4MAT cycle: Desinging instruction for diverse learning styles. California: Corwin Pres.

Mutlu, İ. \& Okur, M. (2012). Bazı geometrik kavramların öğrenilmesine 4MAT öğretim yöntemi ve öğrenme stilinin etkisi. Erzincan Üniversitesi Ĕ̆itim Fakültesi Dergisi, 14(2), $25-48$.

Mutlu, M. (2004). Illköğretim 8. Sinıf fen bilgisi dersinde fotosentez-hücresel solunum konusunun 4MAT öğretim modeli kullanılarak ögretilmesinin öğrenci tutum ve başarısı üzerine etkisi. Yayımlanmamış Doktora Tezi. Gazi Üniversitesi Eğitim Bilimleri Enstitüsü, Ankara.

Neuman, W. L. (2009). Toplumsal araştırma yöntemleri: nitel ve nicel yaklaşımlar: 1. cilt. (Çev. S. Özge). İstanbul: Yayınodası.

Nicoll-Senft, J. (2012). Assessing the impact of 4MAT for college. Institute for Learning Styles Journal, 1, 8-20.

Nowacki, A. S. (2011). Using the 4MAT framework to design a problem-based learning biostatistics course. Journal of Statistics Education, 19(3), 1-24.

Özgen, K. \& Alkan, H. (2014). Yapılandırmacı öğrenme yaklaşımı kapsamında, öğrencilerin öğrenme stillerine uygun öğrenme etkinliklerinin akademik başarı ve tutuma etkileri: Fonksiyon ve türev kavramı örneklemesi. Turkish Journal of Computer and Mathematics Education, 5(1), 1-38.

Öztürk, Z. (2007). Öğrenme stilleri ve 4MAT modeline dayalı öğretimin lise tarih derslerindeki ögrenci başarısına etkisi. Yayımlanmamış Yüksek Lisans Tezi. Gazi Üniversitesi Eğitim Bilimleri Enstitüsü, Ankara.

Peker, M. (2003). Öğrenme stilleri ve 4mat yönteminin ögrencilerin matematik tutum ve başarılarına etkisi. Yayımlanmamış Doktora Tezi. Gazi Üniversitesi Eğitim Bilimleri Enstitüsü, Ankara. 
Inel, Y. (2018) / The effect of 4 mat method on the academic achievement of students in social....

Pratoomtong, W., Haemaprasith, S., Boonprakob, M., \& and Choochom, O. (2012). Effects of science learning activity management based on 4MAT system of the sixth grade students with different learning styles. Journal of Education, 35(1), 67-73.

Scales, A. Y. (2000). The effect of learning style, major, and gender on learning computeraided drawing in an introductory engineering/technical graphics course. Unpublished Doctoral Thesis. North Carolina State University.

Scott, H. V. (1994). A serious look at the 4MAT model. Retrieved from https:// files.eric.ed.gov/fulltext/ ED383654.pdf. 5 December 2018.

Tezcan, G. \& Güvenç, H. (2017). The effects of 4MAT teaching model and whole brain model on academic achievement in science. Education and Science, 42(192), 3003-325.

Tomlinson, C. A. (2007). Öğrenci gereksinimlerine göre farklılaştırılmış eğitim. (Çev. Sev Mat. ve Yay.). İstanbul: Redhouse Eğitim Kitapları.

Tsai, H. S. (2004). Learning achievement satisfaction and retention with whole-brain instruction among nursing students at a technology college in Taiwan. Unpublished Doctoral Thesis. Idaho State University, USA.

Ursin, U. D. (1995). Effects of the 4MAT system of instruction on achievement products and attitudes towards science of ninth grade students. Unpublished Doctoral Thesis. The University of Connecticut, USA.

Usta, A., Bodur, H., Yağız, D. \& Sünbül, A.M. (2011). İlköğretim fen bilgisi derslerinde öğrenme stillerine dayalı öğretim etkinliklerinin öğrenci erişi ve tutumlarına etkisi. Selçuk Üniversitesi Ahmet Keleşoğlu Eğitim Fakültesi Dergisi, 31, 1-13.

Uyangör, S. M. \& Dikkartın, F. T. (2009). 4MAT öğretim modelinin öğrencilerin erişileri ve öğrenme stillerine etkisi. Necatibey Eğitim Fakültesi Elektronik Fen ve Matematik Ĕgitimi Dergisi, 3(2), 178-194.

Uyangör, S. M. (2012). The effectiveness of the 4MAT teaching model upon student achievement and attitude levels. International Journal of Research Studies in Education, 1(2), 43-53.

Uysal, F. (2009). Illkögretim 6. Sinıf matematik dersi kesirler konusunun ögretiminde 4MAT ögrenme stili modelinin ögrenci başarısına etkisi. Yayımlanmamış Yüksek Lisans Tezi. Gazi Üniversitesi, Eğitim Bilimleri Enstitüsü, Ankara.

Williams, T.L. \& Turner, R. C. (2004). Personality and learning style differences in graduate science programs incorporating business skills training. Annual Meeting of the American Educational Research Association, Paper Session: Roundtable 25. New Perspectives on Teaching and Learning, San Diego.

Woolfolk, A. E. (1993). Educational psychology (5th Edition). Boston: Allyn and Bycon.

\section{Biographical statement}

Yusuf INEL is an assistant professor in the Department of Turkish and Social Sciences Education at the Uşak University. He studies on social studies education. 